\title{
Reconstruction of Huge Cutaneous Defects of Thoracic Large Meningomyelocele: A Technical Note
}

\section{Torasik Geniş Meningomyeloselin Dev Kutanöz Defektlerinin Rekonstrüksiyonu: Teknik Not}

\author{
(D) Perçin Karakol1, (D) Nuri Serdar Baş2, (D) Mehmet Bozkurt1, (D) Ece Sağlam²
}

${ }^{1}$ University of Health Sciences Turkey, İstanbul Bağcılar Training and Research Hospital, Clinic of Plastic and Reconstructive Surgery, İstanbul, Turkey

2University of Health Sciences Turkey, İstanbul Bağcllar Training and Research Hospital, Clinic of Neurosurgery, İstanbul, Turkey

\section{Abstract}

In meningomyelocele (MMC) cases, postnatal sac repair and repairment of overlying tissue defect in early period is a challenging surgical process. Infection control, hemodynamic follow-up and selection of the appropriate reconstruction technique are important. Repairment of thoracolumbar huge defects is extremely difficult due to the anomalies of adjacent bony and soft tissues. The aim of the study is to report the method of repairment of the thoracolumbar huge defect in a patient with a large MMC and also to review the options of repairment of such defects and to provide a common surgical discipline. A term newborn with a mainly thoracic large MMC, $10 \times 15 \mathrm{~cm}$ in size, was operated on the $5^{\text {th }}$ postpartum day. After the excision of MMC and repairment of neural tube, operation was performed for the closure of skin defect. Tissue defect was reconstructed with a Z advancement-rotation flap. There were no early or late complications after the operation. We concluded that the repairment of the defects with flaps after giant MMC excisions in a single-session reduces the morbidity.

Keywords: Flap, meningomyelocele, reconstruction

\section{Öz}

\begin{abstract}
Meningomyelosel (MMC) olgularında postnatal kese onarımı ve üstteki doku defektinin erken dönemde tamiri zorlu bir cerrahi işlemdir. Enfeksiyon kontrolü, hemodinamik takip ve uygun rekonstrüksiyon tekniğinin seçimi önemlidir. Torakolomber büyük defektlerin onarımı, bitişik kemik ve yumuşak doku anomalileri nedeniyle son derece zordur. Çalışmanın amacı, MMC'si büyük olan bir hastada torakolomber dev defektin onarım yöntemini bildirmek, bu tür defektlerin onarım seçeneklerini gözden geçirmek ve ortak bir cerrahi disiplin sağlamaktır. Postpartum 5. günde ağırlıklı olarak torasik, $10 \times 15 \mathrm{~cm}$ boyutlarında geniş MMC'li term yenidoğan, önce MMC'nin eksizyonu ve nöral tüp onarımı ardından deri defekti kapatılması için ameliyat edildi. Doku defekti flep ile onarıldı. Operasyon sonrası erken veya geç komplikasyon olmadı. Tek seansta dev MMC eksizyonları sonrası defektlerin fleplerle onarılmasının morbiditeyi azalttığı sonucuna vardık.
\end{abstract}

Anahtar kelimeler: Flap, meningomyelosel, rekonstrüksiyon

\section{Introduction}

Meningomyelocele (MMC) has the priority, among the most severe and complex congenital anomalies compatible with life among the congenital defects involving the spine observed in neurosurgery practice. MMC is herniated from a bone and skin defect, including the spinal cord, nerve roots and meningeal structures. It is a neural tube defect characterized by a completely open (myelochisis) or sac-like lesion. Patients often have motor and sensory defects in the lower extremities, urinary bladder and anal sphincter $(1,2)$. Generally, the relevant segment and nerve roots below it are non-functional.

Prognosis is related to the level of the lesion. Functional prognosis worsens as it rises to higher levels, sphincter

Address for Correspondence: Nuri Serdar Baş, University of Health Sciences Turkey, İstanbul Bağcılar Training and Research Hospital, Clinic of Neurosurgery, İstanbul, Turkey

E-mail: nserdarbas@yahoo.com.tr ORCID: orcid.org/0000-0003-1625-4868 Received: 09.02.2021 Accepted: 06.04.2021

Cite this article as: Karakol P, Baş NS, Bozkurt M, Sağlam E. Reconstruction of Huge Cutaneous Defects of Thoracic Large Meningomyelocele: A Technical Note. Bagcilar Med Bull 2021;6(2):210-215

${ }^{\odot}$ Copyright 2021 by the Health Sciences University Turkey, Bagcilar Training and Research Hospital Bagcilar Medical Bulletin published by Galenos Publishing House. 
dysfunction associated with different levels of motor loss (L1-S1-roots) may be observed (S2-S4 roots). Mostly paraplegia is present in lesions between T10 and L4 levels, and ambulation of the patient is generally not possible (3).

Healthy repair of the meninges and the tissue defect on it prevents serious complications, especially meningitis, reduces the risk of developing an epidermoid/dermoid tumor, which is a kind of embryological residual tumor, and ensures maximum preservation of current sensory and motor functions.

Reconstruction of the defect after the excision of large MMCs is challenging and the viability of flaps is difficult due to the lying position of the children. In patients who are mostly newborns, repair of the meningeal membranes that are resistant to infections and trauma is valuable for the healthy growth of the patient as possible. Also, the fact that most of the cases are in the neonatal period brings some surgical risks along with itself. Closing the defect as soon as possible and in a single session, keeping the bleeding as minimal as possible by tightly control, and completing the surgery with the principle of maximum respect to the tissue reduce the morbidity and mortality.

In this study, we aimed to present the method of repairment of the thoracolumbar huge defect in a patient with large MMC whose primary closure was not possible and also to review the options of appropriate flap selection for repairment of such defects and to provide a common surgical discipline.

\section{Case Report}

On the $5^{\text {th }}$ postpartum day after pregnancy without followup, the baby girl was in a prone position due to the giant mass localized in the mainly thoracic region (Figure 1). There was no family history. The mass was covered with a thin epithelium layer and followed by wet dressing. There was excessive cerebrospinal fluid (CSF) leak. Care was taken to keep the dressing moist with sterile saline for several hours during preoperative follow-up. In the neurological examination of the patient, both lower extremities were plegic. Head circumference was $37 \mathrm{~cm}$, at the $97^{\text {th }}$ percentile.

Magnetic resonance imaging revealed that the vertebral canal was open, the sac was connected to the subarachnoid distance, and there were nerve fibers in it. Hydrocephalus and Chiari type 2 malformation were detected as additional anomalies. The patient, who was diagnosed with MMC, was operated for the excision of the sac and repair of the defect to be formed. Informed consent was obtained from the family of the patient. The patient, whose intubation was performed in the lateral position by anesthesia, was placed in the prone position and surgery was started to be performed. During the entire surgery, care was taken to ensure that the patient was normothermic, and the fluidelectrolyte balance was preserved.

The existing sac was opened in a controlled manner and contents of it were revealed. The area around the sac was freed starting from the superior side of the sac with an incision at the border of the healthy skin around the sac, which was made in a way to preserve the healthy skin tissue where the sac met the lumbar skin, but also not to leave the primitive MMC sac in the area. The excised tissues with primitive epithelium residue were sent to pathology. Then, anatomical tissue definition was made in the skinsubcutaneous distance. It was observed that the cord was in a sheet shaped in the placode. It was tracked that there were neural elements attached to the skin in the sac. The sac was excised, preserving the nerve fibers located on the wall and adjacent to the inner surface. Neural placode was turned into a tube by pia-pial sutures.

The dural tissues were dissected from the base of the sac and primarily sutured by making a tube around the neural tissue. After that, it was ensured that there was no CSF leak by applying positive pressure.

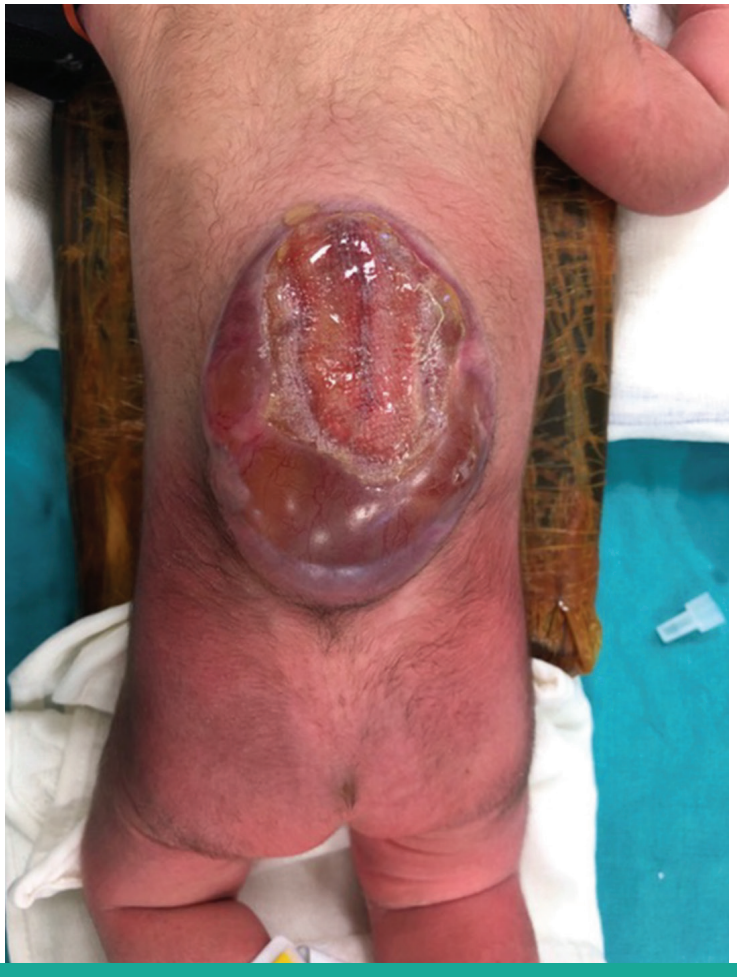

Figure 1. Preoperative view of a giant thoracic mass 
The repairment of huge soft tissue defect was planned by staining and covering. Flaps were elevated by drawing $\mathrm{Z}$ plasty with round angles that centered 90 degrees, one of the midlines of the defect rotated superiorly and the other one inferiorly, by measuring the defect diameter (Figure 2). The lower part of latissimus dorsi muscle was turned as a strip and brought closer to the midline. Donor areas were closed primarily in the lateral areas without stretching (Figure 3). There was no need for drains (4).

In the postoperative period, no dehiscence, necrosis or seroma developed at the wound side. On the postoperative $10^{\text {th }}$ day, sutures were extruded (Figure 4).

\section{Discussion}

Spinal dysraphism is the most important cause of major disabilities in childhood and adulthood (3). MMC is a very serious type of spinal dysraphism and it is well known in neurosurgical and neonatology practice. Its incidence is 1-2 per 1.000 births (5).

Although the anomaly can be located along with the vertebral canal (3), thoracolumbar and lumbosacral localization are the most common regions.

In MMC, the vertebral canal remains open, the meninges protrude out of the skin, and there is a cystic mass associated with the subarachnoid space that is lined with

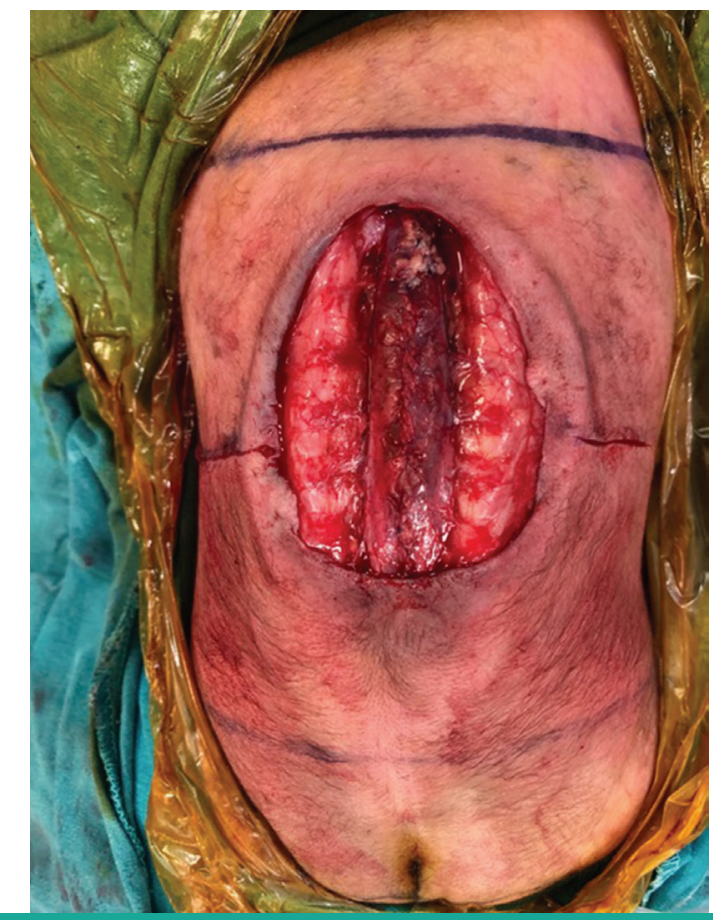

Figure 2. The sac was closed and flap drawings were made epithelium and filled with CSF. In these masses located in the midline, vertebral canal opening and overlying skin defects are observed.
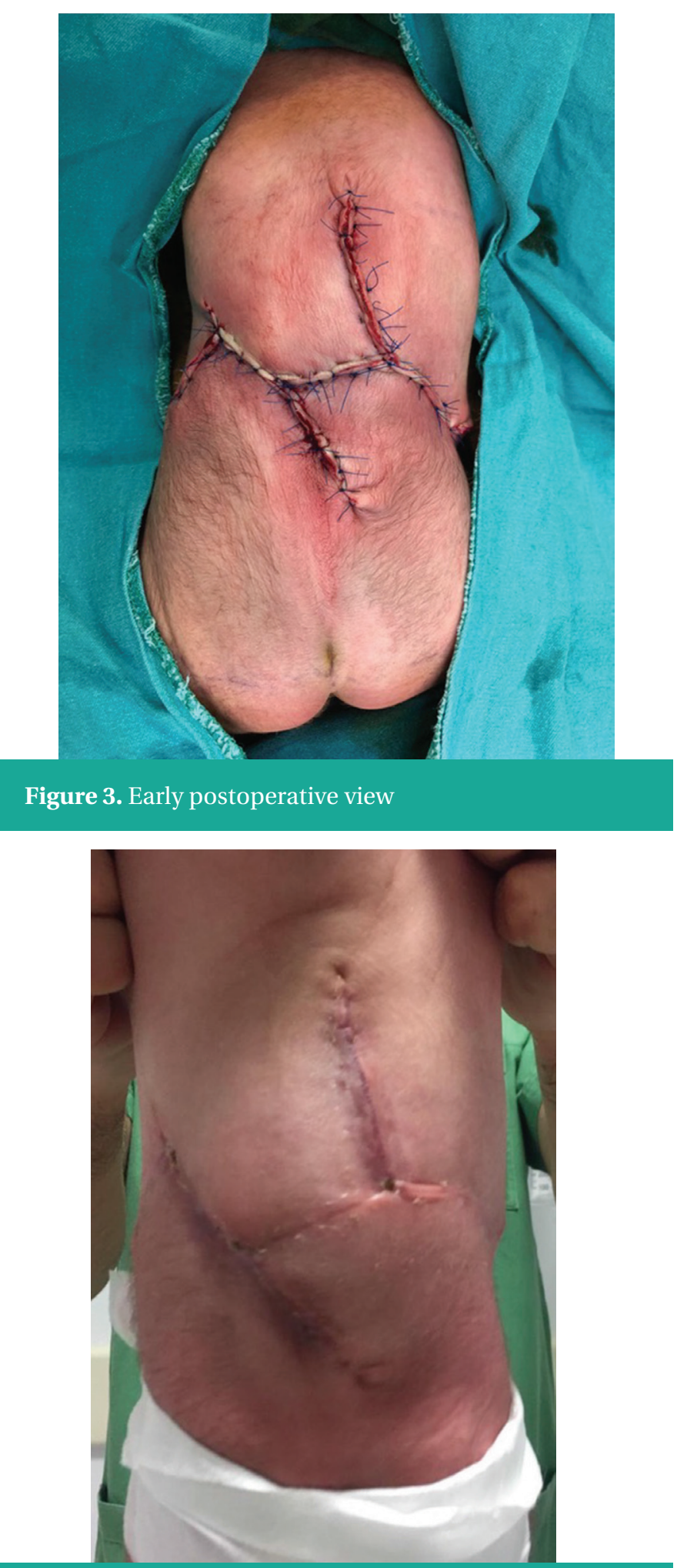

Figure 4. The defect area healed smoothly in the late postoperative period 
Hydrocephalus is present in most (85\%) of MMC cases. A rapid increase in existing hydrocephalus can be observed, especially with the closure of the defect. The newborn should be followed closely with daily fontanel and head circumference monitoring. It should be monitored at the appropriate time for planning shunt surgery.

Prone lying position is recommended for healthy children, especially for the prevention of reflux during infancy process. Newborns with MMC have to lie in this position anyway.

They should be placed in the prone position and neural tissues should be protected from trauma and external factors. Surgery should be planned as soon as the newborn is vitally stable -within the first few days if possibleespecially since they tend to become infected rapidly. The ideal surgical approach is to close the defect within the first 24 hours. Motor examination of the newborn should be evaluated in detail and sphincter functions should be checked. Since orthopedic, urological and cardiac problems may accompany frequently, a multidisciplinary approach should be kept in mind and consultation should be planned if necessary.

The surgical procedure routinely used in MMC practice is primarily to create the neural tube that has not formed yet (6). The surgical procedure performed for this purpose has some key points. The first of them is the completion of removal of the zona epitheliosa layer. It is very important to remove the zona epitheliosa completely in order to prevent future epidermoid cysts. The liberated neural tube should not be closed too tightly in order to prevent the tense spinal cord problem in the future. The second important point is to close the dura, which is the next step after the neural tube is created (6-8). The dura must both coils the neural tube and allows CSF circulation within it. The dura must be dissected from its adhesions in the fascia and must be closed in a watertight fashion.

After closing the dura, the fascia should be closed in accordance with the subcutaneous and skin anatomy. Fascia is very weak, especially in cases with large defects, and may not be fully closed. At this stage, blunt and careful dissections should be preferred over sharp dissections and finger dissection. Bilateral ventral skin dissection towards the abdomen should always be kept in mind to cover small defects, but if there is a need for flap, the surrounding tissue should never be touched for the purpose of forwarding. During the reconstruction phase, the overly tight covering of the layers and their being forced to combine causes necrosis, necessitating a possible secondary surgery, and additional problems come into play by extending the hospitalization period. Therefore, in surgical procedures where the size of the defect is calculated in a way that cannot be easily covered with the surrounding soft tissue, the flap must be designed and drawn before the sac repair and the flap drawing should not be exceeded and the surrounding tissue should be protected.

Healthy repair of meninges and overlying tissue defects in patients prevents serious complications, especially meningitis, and provides maximum protection of sensory and motor functions (3). For reconstruction purposes, primary suturing, skin grafts, $\mathrm{Z}$ plasty, tissue expander applications, rotation and advancement flaps, composite muscle-skin flaps, perforator flaps and free flaps can be used. While some of these are in one session, some cannot be completed in one session.

Primary repair can be preferred only in cases where the defect diameter is less than $5 \mathrm{~cm}$, without creating tension in the suture lines (1). In cases where the defect is larger, it is not possible to repair the defect with primary suturing. At that stage, $\mathrm{Z}$ plasty incisions can be made to extend the tissue edges. Skin grafting may give us a temporary solution during the child's growth phase. Closing a full-thickness defect with only skin causes defects in the compression areas and CSF leakage again according to the position of the decupit. The early or late ulcer opening, even if the graft is adhered, infection development and susceptibility to traumas of skin grafting applications primarily suggest that these types of defects should be repaired with flap. Local skin flaps can provide repairment opportunities close to the desired purposes, as the defect will remain small in small sacs. Single or bilateral skin advancement flaps, bipediculated skin flaps, Limberg flaps and rotation flaps can be selected for the repair of the defect that occurs after large sac excisions. Prolonged operation time, excessive blood loss, and the risk of loss, even if partial, can be considered as disadvantages $(1,2)$. However, flap instead of direct repair, at least, reduces the chance of dehiscence after stretching due to the lying position $(9,10)$. Limberg flap, which is the first choice among local skin flaps, is often advantageous in the use of such defects. The biggest advantage of this type of flaps, which are made with the principle of 120 degrees and 60 degrees, is that there is no need for muscle use, and that the operation time and the amount of bleeding are less. However, when there is a partial or full thickness necrosis, a muscle skin flap should be planned $(8,9)$. Muscle flap removal should be among 
the last options, as there are patients who cannot use their lower extremities in adulthood and need trunk muscles for trunk posture $(11,12)$. Since this situation is directly related to the defect diameter, flap design should be made with appropriate drawings. At the stage of muscle inclusion into the flap, M. latissimus dorsi or M. gluteus maximus can be selected according to the location of the defect (13). Whether one or both muscles will be included in the flap in a split shape depends on the location of the defect. Specifically, different flap options have been introduced. In thoracodorsal flaps, the inclusion of M. latissimus dorsi in the flap ensures safe closure of the defect and offers the option of additional skin graft to the muscle flap in the closure of large defects.

Although graft and flap options are used, dermal tissue equivalents are another alternative and combined with simultaneous skin graft in children who do not have sufficient tissue support or develop fistula (12).

Flap selection in MMC defects also varies according to the location of the defect. While fasciocutaneous flaps are a good choice for defects at all levels, several flaps can be designed at the same time depending on the size of the defect. After giant MMC excisions, if the defect exceeds approximately $60 \%$ of the thoracic region, as in this case, treatment options are limited (14). The latissimus dorsi muscle in the upperlevel settlers and the gluteus maximus muscle in the lumbar local ones can be included in flaps (15). Bottom located defects are more suitable for perforator flaps. In our case, the bilateral latissimus dorsi muscle flap was chosen to support the midline while the drawings were made according to the ZAR flap drawings and the flaps were elevated (4). Limberg flaps were not preferred due to the fact that $60 / 120$ degree drawings might result in necrosis even in partial in such large defects. Since the patient was going to undergo shunt operation in the urgent period, a single-session operation was directed. Tissue expanding application was not the appropriate choice for this patient, as it had two sessions, required a long period of inflation, and could be exposed at times (16). With ZAR flaps, it was observed that the full layer of subcutaneous and skin tissue covering the midline muscle provided a complete compression-resistant tissue integrity. The second advantage of this technique was that there was no need for skin grafts for donor sites, so donor site morbidity was low.

Making perforator flaps requires experience linked to the learning curve. In young children, the chances of success are reduced due to the narrow calibration of the perforator vessels (17). The perforator flap options recommended for lumbar MMC defects are wider. Whittemore et al. (17) described a superior gluteal artery-based perforator flap. It may be preferred in smaller defects and defects close to the sacrum.

\section{Conclusion}

The diameter and location of the defect are important in the reconstruction of thoracic MMC defects. In the closure of very large defects, one session should be planned as early as possible, in a way to keep the operation time short, and in lying position in childhood and the trunk posture in adulthood. In addition, the fact that the selected flap contains muscle tissue reduces the chance of fistula by covering the dural repair area more properly.

\section{Acknowledgments}

The authors thank MD Feyza Karagöz Güzey for her help on this study. This research did not receive any specific grant from funding agencies in the public, commercial, or notfor-profit sectors.

\section{Ethic}

Informed Consent: Written informed consent was obtained from the parents/legal guardians for the publication of this case report and any accompanying images.

Peer-review: Externally peer-reviewed.

\section{Authorship Contributions}

Concept: P.K., N.S.B., Design: P.K., N.S.B., E.S., Data Collection or Processing: P.K., N.S.B., E.S., Analysis or Interpretation: P.K., N.S.B., E.S., Drafting Manuscript: P.K., N.S.B., M.B., E.S., Critical Revision of Manuscript: P.K., N.S.B., M.B., Writing: P.K., N.S.B., M.B., E.S.

Conflict of Interest: The authors declare that there is no conflict of interest with regard to this manuscript.

Financial Disclosure: No financial support was received from a person or a company for writing this case report.

\section{References}

1. Ramirez OM, Ramasastry SS, Granick MS, Pang D, Futrell JW. A new surgical approach to closure of large lumbosacral meningomyelocele defects. Plast Reconstr Surg 1987;80(6):799-809.

2. Luce EA, Walsh J. Wound closure of the myelomeningocele defect. Plast Reconstr Surg 1985;75(3):389-393.

3. McLone DG. Congenital malformations of the central nervous system. Clin Neurosurg 2000;47:346-377.

4. Gümüş N. A new approach to closure of myelomeningocele defect: $\mathrm{z}$ advancement-rotation flap. Ann Plast Surg 2008;61(6):640-645. 
5. Andronikou S, Wieselthaler N, Fieggen AG. Cervical spina bifida cystica: MRI differentiation of the subtypes in children. Childs Nerv Syst 2006;22(4):379-384.

6. Moore KL, Persaud TVN. Formation of germ layers and early tissue and organ differentiation. In The Developing Human, Moore KL, Persaud TVN (eds), 6th ed., Philadelphia: Saunders, 1998:63-80.

7. Rehman L, Shiekh M, Afzal A, Rizvi R. Risk factors, presentation and outcome of meningomyelocele repair. Pak J Med Sci 2020;36(3):422-425.

8. Kemaloğlu CA, Özyazgan İ, Ünverdi ÖF. A decision-making guide for the closure of myelomeningocele skin defects with or without primary repair. J Neurosurg Pediatr 2016;18(2):187-191.

9. El-khatib HA. Large thoracolumbar meningomyelocele defects: incidence and clinical experiences with different modalities of latissimus dorsi musculocutaneus flap. Br J Plast Surg 2004;57(5):411-417.

10. Evrenos MK, Kamburoğlu HO, Seçer M, Çınar K, Dadacı M, İnce B. Clinical outcomes of large meningomyelocele defect repair by bilateral fasciocutaneous rotation and advancement flaps with perforators. Turk J Plast Surg 2017;25(3):113-119.

11. Hosseinpour M, Forghani S. Primary closure of large thoracolumbar myelomeningocele with bilateral latissimus dorsi flaps. J Neurosurg Pediatr 2009;3(4):331-333.
12. Hill SM, Elwood ET, Lin J. Closure of meningomyelocele defects using acellular dermal matrix. J Neurosurg Pediatr 2012;9(2):156160 .

13. McDevitt NB, Gillespie RP, Woosley RE, Whitt JJ, Bevin AG. Closure of thoracic and lumbar dysgraphic defects using bilateral latissimus dorsi myocutaneous flap transfer with extended gluteal fasciocutaneous flaps. Childs Brain 1982;9(6):394-399.

14. Blount JP, George TM, Koueik J, Iskandar BJ. Concepts in the neurosurgical care of patients with spinal neural tube defects: An embryologic approach. Birth Defects Res 2019;111(19):1564-1576.

15. Sarifakioglu N, Bingül F, Terzioglu A, Ates L, Aslan G. Bilateral split latissimus dorsi V-Y flaps for closure of large thoracolumbar meningomyelocele defects. Br J Plast Surg 2003;56(3):303-306.

16. Frykberg T, Olsen L. Tissue expansion facilitates operation of large myelomeningoceles. Z Kinderchir 1990;45(4):242-244.

17. Whittemore BA, Swift DM, Weprin BE, Duffy FJ Jr. Long-term follow-up of superior gluteal artery perforator flap closure of large myelomeningoceles. J Neurosurg Pediatr 2017;19(3):333-338. 